\title{
Penerapan metode debat pro dan kontra untuk meningkatkan proses pembelajaran PPKn
}

\author{
Yuliati ${ }^{\text {a, }}{ }^{*}$ \\ ${ }^{a}$ Guru PPKn SMA N 3 Bantul, Daerah Istimewa Yogyakarta, Indonesia \\ Iyuliati.sma3btl@gmail.com \\ *korespondensi penulis
}

\begin{tabular}{ll}
\hline Informasi artikel & ABSTRAK \\
\hline Kata kunci: & Penelitian ini bertujuan membangun keaktifan belajar untuk meningkatkan hasil belajar \\
debat; & melalui metode debat pro dan kontra pada peserta didik kelas XI IPA 3 SMA 3 Bantul. \\
pro-kontra; & Penelitian dengan menggunakan penelitian tindakan kelas (Classroom Action \\
PPKn & Research) dengan dua siklus. Pengumpulan data dilakukan melalui observasi langsung \\
& saat pembelajaran dan tes. Analisis pengolahan data kuantitatif dengan tes dari \\
& persentase ketuntasan. Data kualitatif dengan observasi peserta didik dalam \\
& menyampaikan pendapat, menanggapi pertanyaan, menghormati pendapat dan kerja \\
& sama. Indikator keberhasilan didasarkan pada rerata persentase peningkatan keaktifan \\
& 85\% peserta didik dengan hasil belajar mencapai ketuntasan belajar $\geq 76$. Hasil \\
& penelitian menunjukkan bahwa penerapan metode debat pro dan kontra dapat \\
& meningkatkan keaktifan dan hasil belajar. Hal ini dilihat dari peningkatan rerata hasil \\
& belajar PPKn dari 73,33 sebelum tindakan, meningkat menjadi 75 pada siklus I dan \\
& mencapai 85,42 pada siklus II.
\end{tabular}

Keywords:

ABSTRACT

debate;

This study explains about building learning activeness to improve learning outcomes

pro-contra; through the method of debate pro and contra on students class XI IPA 3 SMA 3 Bantul.

PPKn

Use Classroom Action Research with two cycles. Data collection is done through direct observation during learning and test. Analysis of quantitative data processing with the test of the percentage of mastery. Qualitative data by observing learners in expressing opinions, responding to questions, respecting opinions and cooperation. The success indicator is based on the percentage of activeness improvement of $85 \%$ of learners with the learning achievement learning achievement $\geq 76$. The results show that the application of pro and contra debate method can improve the activity and learning outcomes. This is seen from the increase of average learning outcomes of PPKn from 73,33 before action, increase to 75 in cycle I and reach 85,42 in cycle II.

\section{Copyright $(92018$ Yuliati. All Right Reserved}

\section{PENDAHULUAN}

Di era global seperti saat ini warga negara perlu memiliki kepribadian bangsa.

Untuk mencapai hal tersebut bagi generasi muda, mata pelajaran Pendidikan Pancasila dan Kewarganegaraan (PPKn) merupakan salah satu sarananya. PPKn mempunyai tujuan antara lain untuk berpikir secara kritis, rasional, dan kreatif dalam menanggapi isu kewarganegaraan dan berpartisipasi secara aktif dan bertanggung jawab, selain itu juga untuk bertindak secara cerdas dalam kegiatan bermasyarakat, berbangsa, dan bernegara, hasil yang diharapkan adalah para siswa sebagai generasi penerus bangsa tetap memiliki kepribadian bangsa Indonesia dan mampu menghadapi kompetisi dan tantangan global. Pendidikan Kewarganegaraan merupakan suatu wahana pendidikan demokrasi yang 
mengandung tiga dimensi konseptual interaktif, yakni kajian ilmiah kewarganegaraan, program kurikuler kewarganegaraan, dan aktivitas sosiokultural kewarganegaraan (Winataputra, 2001, 2014)

Hasil belajar menunjuk pada prestasi belajar peserta didik dalam proses pembelajaran (Hamalik, 2010). Hasil belajar merupakan suatu hal yang dapat dicapai dari dua sisi yaitu sisi siswa dan dari sisi guru. Artinya banyak faktor yang menentukan hasil belajar siswa di sekolah. Proses menentukan hasil belajar juga melibatkan berbagai cara atau metode pengukuran. Maka dalam hal ini hasil belajar sangat berkaitan dengan evaluasi hasil belajar yang diperlukan untuk mengukur, mengolah dan menafsirkan berbagai data yang menjadi pertimbangan untuk memutuskan hasil belajar. Hasil belajar pada hakikatnya adalah kombinasi dari ketiga ranah yang disampaikan Bloom yang telah direvisi oleh Anderson yakni aspek kognitif, afektif dan psikomotor. Dalam konteks PPKn maka yang menjadi pusat perhatian penilaiannya adalah pada ranah civic knowledge, civic skill dan civic disposition untuk membekali peserta didik dengan pengetahuan, budi pekerti, dan kemampuan dasar sebagai warga negara yang baik.

Pada proses pembelajaran yang dilakukan di SMA 3 Bantul, hasil belajar PPKn mencakup ranah kognitif yang diperoleh hasil posttest dengan Kriteria Ketuntasan Minimal 76 dan ranah afektif dengan nilai Kriteria Ketuntasan Minimal B. Diperoleh melalui diskusi dengan siswa bahwa salah satu kesulitan yang dihadapi oleh siswa selama belajar PPKn adalah kemampuan memahami materi yang sangat banyak dan selalu berkembang. Hal ini ditunjukkan dengan rendahnya hasil belajar siswa pada materi hukum internasional yang nilainya telah mencapai KKM hanya $62.5 \%$ (15 siswa) dari 24 siswa. Berdasarkan pengamatan langsung di kelas dan hasil diskusi dengan sesama guru PPKn terungkap bahwa kesulitan siswa adalah metode yang digunakan oleh guru masih berpusat pada guru (ceramah) yang bersifat satu arah sehingga siswa menjadi pasif dan kurang bergairah.

Melihat kenyataan tersebut, untuk memperoleh hasil belajar yang dapat mencapai KKM sebenarnya memang ditunjang dari proses pembelajaran yang baik dengan melibatkan metode pembelajaran yang mendukung proses pembelajaran. Tugas guru adalah mampu memilih berbagai metode yang tepat untuk menciptakan proses belajar mengajar. Metode merupakan kegiatan ilmiah yang berkaitan dengan suatu cara kerja (sistematis) untuk memahami suatu subjek atau objek penelitian, sebagai upaya untuk menemukan jawaban yang dapat dipertanggung jawabkan secara ilmiah dan 
termasuk keabsahannya (Ruslan, 2003). pihak lain yang disebut penyangkal atau Sementara itu metode pembelajaran dapat negatif (Nurdin, 2016).

diartikan sebagai cara yang digunakan untuk

Oleh karena itu, penggunaan metode mengimplementasikan rencana yang sudah disusun dalam bentuk kegiatan nyata dan praktis untuk mencapai tujuan pembelajaran (Sanjaya, 2010). Maka guru hendaknya perlu menentukan metode pembelajaran yang tepat sesuai dengan materi dan kondisi siswa.

Debat merupakan salah satu metode pembelajaran dimana siswa melakukan kegiatan adu argumentasi antara dua pihak atau lebih, baik secara perorangan atau kelompok, dalam mendiskusikan dan memutuskan masalah dan perbedaan. Debat dapat menumbuh kembangkan pola pikir kritis, melatih siswa untuk berani menyampaikan pendapat, menanggapi pertanyaan, menghormati pendapat, menumbuhkan sikap kerja sama antar peseta didik dalam kelompok, menyenangkan, memantapkan pemahaman konsep siswa terhadap materi pelajaran yang telah diberikan, dan dapat meningkatkan hasil belajar PPKn khususnya. Melalui metode debat, siswa didorong untuk mengemukakan pendapatnya melalui suatu perdebatan antar kelompok diskusi yang disatukan dalam sebuah diskusi kelas untuk menentukan baik tidaknya suatu usul tertentu yang didukung oleh suatu pihak yang disebut pendukung atau afirmatif, dan ditolak, disangkal oleh debat dalam pembelajaran PPKn dengan debat pro dan kontra untuk meningkatkan hasil belajar siswa terhadap materi hukum internasional pada siswa kelas XI IPA 3 SMA Negeri 3 Bantul. Penggunaan metode debat ini untuk mengetahui apakah metode pembelajaran debat pro dan kontra dapat mengaktifkan siswa serta meningkatkan hasil belajar siswa terhadap materi hukum internasional.

\section{METODE}

Metode yang digunakan adalah penelitian tindakan kelas (Classroom Action Research) yang menggunakan variabel masalah sebagai fokus utama untuk menjawab permasalahan yang dihadapi. Variabel masalah terdiri dari input, proses pembelajaran, dan output. Langkah penelitian yang dilakukan menyesuaikan prinsip dasar penelitian tindakan kelas (PTK) yang terdiri atas berbagai tahapan yakni perencanaan (planning), pelaksanaan (acting), pengamatan (observing) dan refleksi (reflecting). Sumber data yang digunakan adalah siswa, dokumen hasil belajar, dan proses pembelajaran dengan menerapkan metode debat pro dan kontra dengan jenis data kualitatif meliputi dokumen, data hasil observasi yang selanjutnya dianalisis dengan analisis deskriptif. 
Penelitian dilaksanakan di SMA Negeri

3 Bantul, Daerah Istimewa Yogyakarta. Subjek penelitian adalah kelas XI IPA 3 SMA Negeri 3 Bantul yang berjumlah 24 siswa. Dilaksanakan dalam dua siklus, tiap siklus terdiri dari dua pertemuan, yang meliputi perencanaan, pelaksanaan, pengamatan dan refleksi. Pengumpulan data dilakukan dengan observasi dan tes. Observasi dilakukan pada guru dan siswa. Observasi yang dilakukan kepada siswa difokuskan pada kemauan menyampaikan pendapat, menjawab pertanyaan, menghormati pendapat dan kerja sama, sedangkan observasi pada guru difokuskan pada pemilihan metode, alokasi waktu, penggunaan bahasa dan refleksi penilaian.

Metode analisis data kualitatif dengan observasi dan data kuantitatif dengan tes. Kriteria penilaian dengan nilai antara 0 100. Kriteria keberhasilan dari pemberian tindakan adalah jika $85 \quad \% \quad$ siswa menunjukkan keaktifan belajar dan dampaknya $85 \%$ siswa mendapatkan hasil belajar $\geq 76.00$ (sesuai KKM).

\section{HASIL DAN PEMBAHASAN}

\section{Deskripsi Kondisi Awal}

Sebelum pelaksanaan penelitian, dilakukan pengamatan pendahuluan di kelas yang menjadi subjek dalam penelitian yaitu kelas XI IPA 3 SMA 3 Bantul. Pengamatan difokuskan pada seluruh kegiatan proses pembelajaran PPKn yang dilaksanakan di kelas khususnya terkait dengan metode dan hasil belajar siswa dalam pembelajaran. Berdasarkan pengamatan langsung di kelas dan hasil diskusi sesama guru PPKn terungkap bahwa metode yang digunakan dalam pembelajaran masih berpusat pada guru (ceramah) sehingga siswa menjadi pasif dan kurang eksploratif. Hasil belajar siswa yang dicapai ditunjukkan dengan hasil ulangan harian siswa dapat diketahui bahwa prestasi belajar siswa sebelum tindakan hanya $62.5 \%$ siswa yang tuntas artinya belum mencapai $85 \%$ siswa yang tuntas. Nilai rata- rata hanya 73.33 sehingga masih kurang dari harapan yaitu nilai rata- rata $\geq$ 76. Aktivitas siswa rata- rata hanya $46.5 \%$ dari target $85 \%$.

\section{Deskripsi Siklus I}

\section{Hasil Penelitian}

Tahap perencanaan pada siklus pertama meliputi: mengembangkan silabus, menyusun Rencana Pelaksanaan Pembelajaran (RPP), menyiapkan video, menyusun tema dan rubrik untuk debat, menyusun kelompok pro yang terdiri 9 siswa dan kelompok kontra yang terdiri 15 siswa dengan mempertimbangkan penyebaran siswa yang menguasai materi yang telah disampaikan sebelumnya secara merata, menyusun instrument. Instrumen penelitian meliputi: pedoman penskoran, rubrik evaluasi, lembar observasi , laptop, LCD.

Pelaksanaan pada siklus pertama mengambil kompetensi dasar yaitu mendeskripsikan sistem hukum dan 
peradilan internasional. Langkah- langkah dalam pembelajaran meliputi pembukaan, inti dan penutup. Pembelajaran dimulai apersepsi, penjelasan umum tentang proses pembelajaran yang akan dilaksanakan yaitu dengan metode debat pro dan kontra, membagi siswa dalam dua kelompok pro dan kontra, memutar video, memfasilitasi dan mengarahkan pelaksanaan debat apabila terjadi kesalahan konsep, bersama kolaborator mengamati siswa dalam pelaksanaan debat serta mencatat kejadian yang penting selama proses pembelajaran. Setelah kegiatan inti selesai guru membimbing siswa membuat rangkuman.

Observasi dilakukan oleh kolaborator terhadap aktivitas guru dan peserta didik pada saat berlangsungnya proses pembelajaran. Observasi terhadap siswa ditekankan pada kemauan siswa untuk menyampaikan pendapat, menanggapi pertanyaan, menghormati pendapat dan kerja sama. Observasi pada guru ditekankan pada pemilihan metode, optimalisasi media, alokasi waktu pembelajaran, refleksi penilaian dan penggunaan bahasa. Prestasi belajar siswa pada siklus satu, dari 24 siswa, yang tuntas sebanyak 17 (70.83\%) dengan rata- rata 75 .

Dari pengolahan data hasil observasi maka refleksi ini disimpulkan bahwa Refleksi pembelajaran dengan metode debat pro dan kontra pada siklus satu menunjukkan sebagai berikut, yakni (1) penggunaan metode debat pro dan kontra ternyata sangat disenangi siswa sehingga tingkat partisipasi siswa dalam pembelajaran tinggi, (2) belum semua siswa aktif dalam debat, (3) kemampuan menyampaikan pendapat dan menanggapi pertanyaan perlu ditingkatkan, (4) pada saat debat pada umumnya siswa belum menguasai materi dengan baik, (5) guru mulai mampu mendorong aktivitas siswa dalam pembelajaran, dan (6) prestasi belajar siswa sudah ada kenaikan walaupun belum optimal, pencapaian ketuntasan belajar belum mencapai indikator yang diharapkan.

Hasil prestasi belajar peserta didik belum memenuhi indikator keberhasilan tindakan karena ketuntasan belajar klasikal yang dicapai baru $70.83 \%$ dari $85 \%$ sehingga perlu dilakukan siklus kedua dengan memperbaiki kendala- kendala yang ada.

\section{Siklus II}

Pada siklus kedua perencanaan tindakan memperhatikan hasil refleksi pada siklus pertama. Siklus kedua dimulai dengan pengembangan silabus, menyusun rencana pelaksanaan pembelajaran (RPP), menyiapkan video, penyusunan rencana kegiatan pembelajaran, dengan memperhatikan refleksi siklus pertama dengan beberapa perubahan, antara lain jumlah kelompok pro diubah menjadi 11 orang dan kelompok kontra jumlahnya 13 orang, materi video diganti tentang 
intervensi kemanusiaan dalam konflik Kosovo, siswa diminta untuk mencari materi di internet terkait dengan intervensi kemanusiaan dalam konflik Kosovo.

Pada siklus kedua langkah-langkah dalam pembelajaran meliputi pembukaan, kegiatan inti dan penutup. Pembelajaran dimulai dengan menyiapkan peserta didik secara psikis dan fisik untuk mengikuti proses pembelajaran, dilanjutkan dengan berdoa. Setelah itu Guru mengajukan pertanyaan tentang empat jenis pelanggaran HAM berat untuk mengaitkan materi sebelumnya dengan materi yang akan dipelajari sebagai apersepsi, menyampaikan tujuan pembelajaran yang hendak dicapai da menginformasikan metode pembelajaran yang akan digunakan yaitu metode debat pro dan kontra. Selanjutnya dalam kegiatan inti siswa dengan dibimbing guru mengamati video tentang konflik Kosovo, kemudian menyampaikan stamen terkait dengan intervensi kemanusiaan dalam konflik Kosovo, kemudian kelompok pro dan kontra menyampaikan argumentasinya secara bergantian.

Hasil pengamatan pengelolaan pembelajaran yang dilakukan observer dalam pembelajaran PPKN pada siklus kedua untuk keaktifan siswa persentase ketercapaian yang didapat sebesar $87.5 \%$ dengan kategori keberhasilan sangat tinggi, sedangkan prestasi belajar persentase ketercapaian yang didapat sebanyak $91.67 \%$ siswa tuntas dalam pembelajaran dan nilai rata- rata 85.42 dengan kategori sangat baik. Hasil observasi pada guru menunjukkan bahwa kemampuan guru untuk mengelola pembelajaran sangat baik yaitu bersikap terbuka, bisa memotivasi siswa menjadi aktif dalam pembelajaran, suasana pembelajaran menyenangkan, pemilihan metode, optimalisasi media dan pengembangan karakter dan refleksi untuk mencapai tujuan sangat baik.

\section{Refleksi}

Dari hasil pengamatan terhadap proses pembelajaran pada siklus kedua ini, kita dapat mengetahui bahwa metode debat pro dan kontra, dengan beberapa tindakan perbaikan dari hasil refleksi Pada siklus pertama, dapat mengaktifkan siswa dalam kegiatan pembelajaran yang ditandai dengan peningkatan rata-rata jumlah siswa yang menyampaikan pendapat, menanggapi pertanyaan yaitu dari $66.5 \%$ pada siklus satu menjadi $87.5 \%$ pada siklus kedua. Angka tersebut telah melebihi kriteria keaktifan siswa selama proses pembelajaran yang ditargetkan yaitu sebesar $85 \%$. Siswa juga mengalami pemahaman konsep yang ditandai dengan peningkatan hasil belajar dari rata- rata hasil test 73.33 sebelum tindakan, meningkat menjadi 75 pada siklus satu dan 85.42 pada siklus kedua, untuk ketuntasan belajar dari $62.5 \%$ sebelum tindakan ,meningkat menjadi $70.83 \%$ pada siklus satu dan $91.67 \%$ pada siklus kedua. 
Dengan kriteria keaktifan siswa yakni: 1\% $20 \%$ (sangat rendah), 21\% - 40\% (rendah), $41 \%-60 \%$ (cukup), $61 \%$ - 80\% (tinggi) dan $81 \%$ - $100 \%$ (sangat tinggi), maka rerata tingkat keaktifan siswa pada siklus kedua masuk kategori sangat tinggi. Ketuntasan belajar yang mencapai $87.5 \%$ (23 siswa) telah melampaui kriteria keberhasilan belajar siswa yang telah ditargetkan yaitu $85 \%$ siswa mendapatkan hasil belajar $\geq 76$.

Peningkatan Keaktifan dan Hasil Belajar PPKn Materi Hukum Internasional Menggunakan Metode Debat Pro Dan Kontra

Peningkatan keaktifan dan hasil belajar dapat dilihat dari hasil observasi langsung dalam proses pembelajaran dengan menggunakan metode debat pro dan kontra pada siklus I dan siklus II. Pembelajaran dengan menggunakan metode debat pro dan kontra merupakan upaya untuk memperbaiki pembelajaran yang masih terpusat pada guru. Pelaksanaannya dimulai dengan berdoa, presensi, penjelasan umum tentang langkah-langkah debat. Pembagian kelompok pro yang terdiri 9 siswa dan kelompok kontra yang terdiri 15 siswa dan kontra, pemutaran video, Debat.

Untuk peningkatan keaktifan siswa, sebelum diputarkan video, semua siswa diminta untuk mengamati dengan cermat, setelah itu diminta untuk menanggapi terhadap pertanyaan dari guru terkait dengan video yaitu tentang hukum humaniter secara bergantian antara kelompok Pro dan kontra. Penggunaan media audio visual merupakan hal penting dan menambah pengetahuan serta pemahaman bagi siswa. Dalam pembelajaran PPKn mencari dan menentukan media dan sumber belajar sangat penting sebab bahan ajarnya sangat dinamis. Media dalam kegiatan pembelajaran dianggap tidak hanya sebagai alat bantu namun penyampai infomasi kepada siswa (Dharma, 2012).

Debat merupakan sebuah proses latihan memahami pendapat orang lain yang berbeda (Tilaar, 2013). Debat dapat dilakukan dalam proses pembelajaran karena agar siswa selalu dimotivasi untuk berani menyampaikan pendapat, menanggapi pertanyaan, menghormati pendapat dan kerja sama antar peseta didik dalam kelompok. Debat pro dan kontra menekankan pada aktivitas siswa dalam hal berani menyampaikan pendapat dan mempertahankan pendapatnya, menanggapi pertanyaan, menghormati pendapat dan kerja sama. Hal ini sesuai dengan prinsip keaktifan dalam pembelajaran yang perlu digali agar peserta didik dapat mengembangkan kompetensinya. Sesuai dengan prinsip dalam pembelajaran bahwa pembelajaran merupakan proses aktif peserta didik yang dapat mengembangkan potensi dirinya (Tilaar, 2013). Dengan menggunakan metode debat pro dan kontra ini diharapkan ada peningkatan terhadap 
aktivitas dan hasil belajar PPKN. sendiri secara lebih luas, mendalam dan Keberhasilan proses pembelajaran dalam penelitian tindakan ini ditunjukkan dengan meningkatnya aktivitas dan hasil belajar PPKN, yang perbandingannya dapat dilihat pada peningkatan setiap indikator dan persentase rerata aktivitas dan hasil belajar yang dicapai dari hasil tindakan siklus I dan siklus II.

Pada siklus I, Peningkatan aktivitas siswa dalam pembelajaran ditunjukkan dengan adanya kenaikan persentase siswa dalam hal menyampaikan pendapat, menanggapi pertanyaan, menghormati pendapat dan kerja sama dengan kategori minimal baik, dari $46.5 \%$ sebelum tindakan menjadi $66.5 \%$ siswa yang aktif pada siklus I dan $87.5 \%$ pada siklus II .Peningkatan hasil belajar ini ditunjukkan dengan meningkatnya rata- rata hasil posttest dari 71 sebelum tindakan, menjadi 75 pada siklus I, dan 85 pada siklus II . Persentase hasil posttest siswa yang telah mencapai nilai KKM ( $\geq 76$ ) yaitu $62.5 \%$ dari sebelum tindakan menjadi $70.83 \%$ pada siklus I dan $87.5 \%$ pada siklus II .

Berdasarkan hal tersebut terlihat proses peningkatan keaktifan peserta didik. Produksi pengetahuan melalui proses pembelajaran meningkat. Hal ini tidak lepas dari metode yang diterapkan yakni debat pro dan kontra. Dalam prinsip pembelajaran berpusat pada siswa, dijelaskan bahwa peserta didik memproduksi pengetahuan maju dengan memodifikasi pemahaman terhadap kondisi awal pengetahuan (prior knowledge) (Tilaar, 2013:28). Hal inilah yang terjadi dalam proses pembelajaran yang dilakukan, dan efektifitas suatu proses pembelajaran dipengaruhi oleh beberapa faktor, diantaranya adalah guru, siswa, materi, metode atau pendekatan dan media pembelajaran serta evaluasi (Arpannudin, Abdulkarim, \& Bestari, 2015).

\section{SIMPULAN}

Dari hasil penelitian ini dapat disimpulkan bahwa penggunaan metode Debat Pro Dan Kontra dalam pembelajaran PPKn dapat meningkatkan aktivitas dan hasil belajar PPKn materi Hukum Internasional pada siswa kelas XI IPA 3 SMA Negeri 3 Bantul. Peningkatan aktivitas siswa dalam pembelajaran ditunjukkan dengan adanya kenaikan persentase siswa dalam hal menyampaikan pendapat, menanggapi pertanyaan, menghormati pendapat dan kerja sama dengan kategori minimal baik, dari $46.5 \%$ sebelum tindakan menjadi $66.5 \%$ siswa yang aktif pada siklus I dan $87.5 \%$ pada siklus II .Peningkatan hasil belajar ini ditunjukkan dengan meningkatnya rata- rata hasil posttest dari 71 sebelum tindakan, menjadi 75 pada siklus I, dan 85 pada siklus II . Persentase hasil posttest siswa yang telah mencapai nilai KKM ( $\geq 76$ ) yaitu $62.5 \%$ dari sebelum tindakan menjadi $70.83 \%$ pada siklus I dan 
$87.5 \%$ pada siklus II. Maka debat merupakan metode yang sesuai dengan karakteristik peserta didik di SMA 3 Bantul. Pengalaman dan kreativitas pembelajaran melalui metode pembelajaran sangat perlu dikembangkan agar peserta didik berkembang dan guru termotivasi untuk selalu berinovasi.

\section{UCAPAN TERIMA KASIH}

Penulis mengucapkan terima kasih kepada civitas akademik di SMA N 3 Bantul yang telah membantu proses penelitian. Selain itu penulis menyampaikan terima kasih kepada MGMP PPKn Kabupaten Bantul yang senantiasa memberikan semangat dan dukungan bagi guru-guru PPKn di Kabupaten Bantul untuk selalu berkarya. Selanjutnya diucapkan terima kasih kepada redaksi yang telah mempublikasikan artikel hasil penelitian ini sehingga penelitian ini dapat dibaca oleh berbagai kalangan. Hasil penelitian ini tentunya masih dapat dikembangkan ke dalam bentuk penelitian lain. Harapannya penelitian ini menjadi referensi penelitian selanjutnya. Semoga hasil penelitian ini bermanfaat bagi perkembangan ilmu pengetahuan. Semoga teman-teman guru semakin semangat membuat karya penelitian.

\section{DAFTAR PUSTAKA}

Arpannudin, I., Abdulkarim, A., \& Bestari, P. (2015). Pengaruh media video dengan pendekatan saintifik dalam pembelajaran $\mathrm{PKn}$ terhadap sikap antikorupsi siswa di SMAN 8 Bandung. CIVICUS, 19(1), 57-72.

Dharma, S. (2012). Pengembangan media pembelajaran multimedia interaktif untuk meningkatkan minat dan hasil belajar peserta didik pada pelajaran pendidikan kewarganegaraan (Studi research and development di SMP Pasundan 1 Bandung). Sekolah Pascasarjana Universitas Pendidikan Indonesia.

Hamalik, O. (2010). Proses belajar mengajar. Jakarta: Bumi Aksara.

Nurdin, M. (2016). Penerapan metode debat aktif untuk meningkatkan kemampuan berdiskusi mahasiswa dalam pembelajaran Konsep Dasar PKn di PGSD UPP Bone FIP UNM. Jurnal Publikasi Pendidikan, VI(1), 1-7.

Ruslan, R. (2003). Metode penelitian PR dan komunikasi. Jakarta: Raja Grafindo.

Sanjaya, W. (2010). Strategi pembelajaran berorientasi standar proses pendidikan. Jakarta: Kencana Prenada Media.

Tilaar, H. A. R. (2013). Media pembelajaran aktif. Bandung: Nuansa Cendekia.

Winataputra, U. S. (2001). Jatidiri Pendidikan Kewarganegaraan sebagai pendidikan demokrasi. Disertasi. Sekolah Pascasarjana Universitas Pendidikan Indonesia.

Winataputra, U. S. (2014). Diskursus aktual 
tentang paradigma Pendidikan

Kewarganegaraan dalam konteks

kurikulum 2013. In Seminar Nasional

AP3KNI (hal. 1-12). Surakarta:

AP3KNI dan Universitas Negeri

Sebelas Maret. 